\title{
'My family's goals are also my goals': the relationship between collectivism, distal utility value, and learning and career goals of international university students in Germany
}

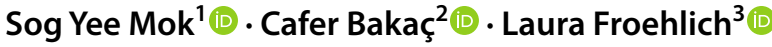

Received: 4 June 2020 / Accepted: 29 October 2020 / Published online: 20 November 2020

(c) The Author(s) 2020

\begin{abstract}
The utility value of an academic task can affect university students' learning behavior and career choices. For collectivistic-oriented students, learning and career goals also matter to their families. Following expectancy-value theory, we assumed that families' achievement-related expectations would affect collectivistic-oriented students' utility value. We conducted a survey study with 154 international university students in Germany. We found a significant mediation effect of students' distal utility value of their university coursework on the relationship between students' collectivism, learning goal orientation, and motivation to follow family-oriented distal career goals, respectively. Practical implications for career counselors and university teachers are discussed.
\end{abstract}

Keywords Collectivism · Expectancy-value theory $\cdot$ Learning and career goals

\section{Résumé}

«Les objectifs de ma famille sont aussi mes objectifs »: La relation entre le collectivisme, la valeur utilitaire distale et les objectifs d'apprentissage et de carrière des étudiants universitaires internationaux en Allemagne La valeur utilitaire d'une tâche académique peut affecter le comportement d'apprentissage et les choix de carrière des étudiants universitaires. Pour les étudiants guidés par des valeurs du collectivisme, les objectifs d'apprentissage et de carrière sont également importants pour leur famille. En se basant sur la théorie d'expectancy-value, nous avons supposé que les attentes des familles quant à la réussite académique auraient une incidence sur la valeur utilitaire d'une tâche académique des étudiants guidés par des valeurs

Sog Yee Mok

sogyee.mok@ife.uzh.ch

1 University of Zurich, Kantonsschulstrasse 3, 8001 Zurich, Switzerland

2 Technical University of Munich, Arcisstraße 21, Munich 80333, Germany

3 FernUniversität in Hagen, Universitätsstr. 33, Hagen 58084, Germany 
du collectivisme. Nous avons mené une étude auprès de 154 étudiants universitaires internationaux en Allemagne. Nous avons trouvé un effet significatif de médiation de la valeur utilitaire distale des cours universitaires des étudiants sur la relation entre le collectivisme des étudiants, l'orientation des objectifs d'apprentissage et la motivation à suivre les objectifs de carrière distaux orientés sur la famille, respectivement. Les implications pratiques pour les conseillers d'orientation et les professeurs d'université sont discutées.

\section{Zusammenfassung}

"Die Ziele meiner Familie sind auch meine Ziele": Der Zusammenhang zwischen Kollektivismus, distaler Nützlichkeit, Lernzielorientierung und zukünftigen Berufszielen von internationalen Studierenden in Deutschland Die Nützlichkeit einer akademischen Aufgabe kann das Lernverhalten und die Berufsentscheidungen von Studierenden beeinflussen. Für kollektivistisch-orientierte Studierende sind Lern- und Berufsziele auch für ihre Familien von Bedeutung. In Anlehnung an die Erwartung-Wert-Theorie wird angenommen, dass die Leistungserwartungen von Familien die Nützlichkeit von kollektivistisch-orientierten Studierenden beeinflussen können. Es wurde eine Fragebogenstudie mit 154 internationalen Studierenden in Deutschland durchgeführt. Es zeigte sich ein signifikanter Mediationseffekt der distalen Nützlichkeit des Studiengangs für Studierende für den Zusammenhang zwischen Kollektivismus und Lernzielorientierung bzw. Motivation familienorientierten distalen Berufszielen zu folgen. Praktische Implikationen für Berufsberatende und Hochschuldozierende werden diskutiert.

\section{Resumen}

"Los objetivos de mi familia también son mis objetivos": la relación entre el colectivismo, el valor de utilidad remota y los objetivos de aprendizaje y carrera de los estudiantes universitarios internacionales en Alemania El valor de utilidad de una tarea académica puede afectar el comportamiento de aprendizaje y las decisiones profesionales de los estudiantes universitarios. Para los estudiantes de orientación colectivista, las metas de aprendizaje y carrera también son importantes para sus familias. Siguiendo la teoría del valor de la expectativa, asumimos que las expectativas de las familias relacionadas con el rendimiento afectarían el valor de utilidad de los estudiantes de orientación colectivista. Realizamos un estudio tipo encuesta con 154 estudiantes universitarios internacionales en Alemania. Encontramos un efecto de mediación significativo del valor de utilidad remota que los estudiantes dan a sus cursos universitarios sobre la relación entre el colectivismo de los estudiantes, la orientación a los objetivos de aprendizaje y la motivación para seguir los objetivos profesionales remotos orientados a la familia, respectivamente. Se discuten las implicaciones prácticas para los orientadores profesionales y los profesores universitarios. 


\section{Introduction}

International university students leave their home country to study in order to gain new experiences and increase their educational and economic success. International mobility of students can be a resource not only for the students themselves, but also for the host country. However, as international students come from heterogeneous backgrounds which are more or less culturally different from the host country, understanding their motivation is relevant for ensuring their academic success. Good grades are important to international university students during their university studies, but also to their family, because good grades increase job prospects in the host country. The academic expectations of the family can in turn enhance students' motivation to engage in learning (Verkuyten, Thijs, \& Cana$\tan , 2001)$. The study and career motivation of international university students in Germany and the influence of students' families on their academic motivation are especially pivotal because they can address the skilled labor shortage in some professions (Winkelmann, 2001). International students from different countries have come to Germany for many years to start a university study program (Bessey, 2012). In the winter semester 2017, one-third of the international students in Germany were originally from China, India, Russia, Syria, or Turkey (HoffmeyerZlotnik \& Grote, 2019), which are collectivistic-oriented countries. Studies have shown that international students are confronted with different challenges such as language barriers and discrimination which might impair their graduation or attainment of their career goals (Franco, Hsiao, Gnilka, \& Ashby, 2019; Schneider, 2018). Hence, it is crucial for university career counselors and university teachers to know what motivates international students during their studies, especially in learning situations, and how international students can be supported to successfully graduate.

According to the expectancy-value theory by Eccles (e.g., Eccles, Adler, Futterman, Goff, \& Kaczala, 1983), achievement-related choices (e.g., practice opportunities) and career goals are affected by subjective task values such as utility value and expectations for success. In this theory, families can indirectly influence students' utility value and expectations for success, which both in turn affect the career choice. Utility value "captures more" extrinsic "reasons for engaging in a task, such as doing a task not for its own sake, but to reach some desired end state" (Wigfield, $\&$ Eccles, 2000, p. 73). For instance, an academic task has a positive utility value to a student when it facilitates crucial goals in the future, even if the student is not personally interested in it (Eccles \& Wigfield, 2002). Utility value can be proximal (i.e., the task is relevant for reaching immediate goals like everyday activities) or distal (i.e., it is relevant for long-term goals like future career plans; Simons, Dewitte, \& Lens 2004). The utility value of a school-related task can be crucial for students' learning behavior, learning goal orientations, and career choices (Dweck \& Leggett, 1988; Eccles et al., 1983). To attain future career goals, motivation defined by one's Future Time Perspective (FTP) also plays a role (e.g., de Volder \& Lens, 1982), because having a longer FTP enables one to anticipate consequences of present activities and stay motivated to achieve a future goal (Husman \& Lens, 1999). 
Most studies on utility value, learning goal orientation, and career goals based on expectancy-value theory and FTP theories have been conducted with individualisticoriented students (e.g., Eccles \& Wigfield, 2002; for a review, see Simons, Vansteenkiste, Lens, \& Lacante, 2004). The lack of empirical evidence for cross-cultural generalizability of expectancy-value theory was addressed in a review chapter by Wigfield, Tonks, \& Eccles (2004). The authors propose that "the processes associated with cultural socialization should influence the ways in which members of cultural groups see themselves as well as the goals and values they develop for their lives" (p. 172). In line with this, we argue that the motivational constructs defined in expectancy-value theory might have a different role for more collectivistic-oriented students because of the core elements of the cultural value orientation of collectivism (e.g., strong relatedness to family members) that have an impact on students and adults (Cross, Bacon, \& Morris, 2000; Oyserman, Coon, \& Kemmelmeier, 2002). Based on these core elements, collectivistic-oriented parents have high academic expectations for their children, which their children strive to meet for the sake of their parents (Cheung \& Pomerantz, 2012). Furthermore, for many collectivistic-oriented individuals, their academic and career decisions as adults still are related to family obligations (e.g., financial support; Fuligni, 2001). Wigfield et al. (2004) discuss that collectivism might play a role for utility value in that "[i]n cultures characterized as collective, utility may not just reflect the usefulness of the activity to the individual, but also to its larger social group. The concern about the group actually could outweigh the utility to the individual" (p. 189). Thus, based on the expectancy-value framework, we assume that the family's collectivism will influence children's utility value which in turn affects the achievement-related choices and career goals. Previous research has shown that collectivistic-oriented students (from East-Asian countries like China, South Korea, and Japan) show increased interest in a task after a utility value intervention emphasizing the distal utility value of the task for their future study and career goals (Kera \& Nakayama, 2017; Shechter, Durik, Miyamoto, \& Harackiewicz, 2011). This greater focus on distal utility value has been shown to be explained by students' future time perspective, which is more strongly endorsed by collectivistic-oriented individuals (e.g., Nisbett, Peng, K., Choi, \& Norenzayan, 2001; Song \& Jiang, 2019). However, it is still unclear how this greater emphasis on distal utility value on collectivistic-oriented students can be explained. Little is known about how expectations and goals of collectivistic-oriented parents affect perceptions of utility value and motivation to engage in achievement-related distal career goals of international university students. This is surprising as the study and career motivation of international university students at the host country and the influence of family's expectations on these students' academic motivation can help to reduce the skilled labor shortage in the host country (e.g., Winkelmann, 2001). Thus, the present study addresses this gap and helps to further develop the cross-cultural validity of expectancy-value theory. 


\section{Theoretical framework: expectancy-value theory for achievement-related and career choices}

We used the expectancy-value theory by Eccles (e.g., Eccles et al. 1983) as a theoretical framework for our current research. In line with our aim of the study and to reduce the complexity of all variables used in the expectancy-value model by Eccles et al., we look only on a portion of the model (for our modified theoretical framework, see Figure 1). According to expectancy-value theory, families as socializers can influence students' achievement-related expectations, which affect students' utility value and expectancy of success. Both utility value and expectancy of success in turn have impact on their achievement-related choices such as choosing extra course or practice opportunities. These achievement-related choices influence students' career choice. As we are interested in motivational outcomes in our study, we focused on motivation towards achievement-related choices that is closely connected to career goals. Importantly, the cultural beliefs of families such as collectivism, emphasizing that children should live up to their families' achievement-related expectations, can shape students' own collectivism (Verkuyten et al., 2001) and, therefore, can also affect their utility value and achievement-related choices. Furthermore, students might be motivated to select achievement-related choices that improve their achievement. Such motivation in learning situations can be students' learning goal orientation (i.e., motivation with the aim to develop one's own abilities; Dweck \& Leggett, 1988) or the motivation to pursue a distal career goal (Husman \& Lens, 1999) which is additionally influenced by the families' collectivism. This influence of families' expectations on children's achievement-related choices and career goals has been particularly shown for individuals from collectivistic-oriented cultures (Fuligni, 2001).

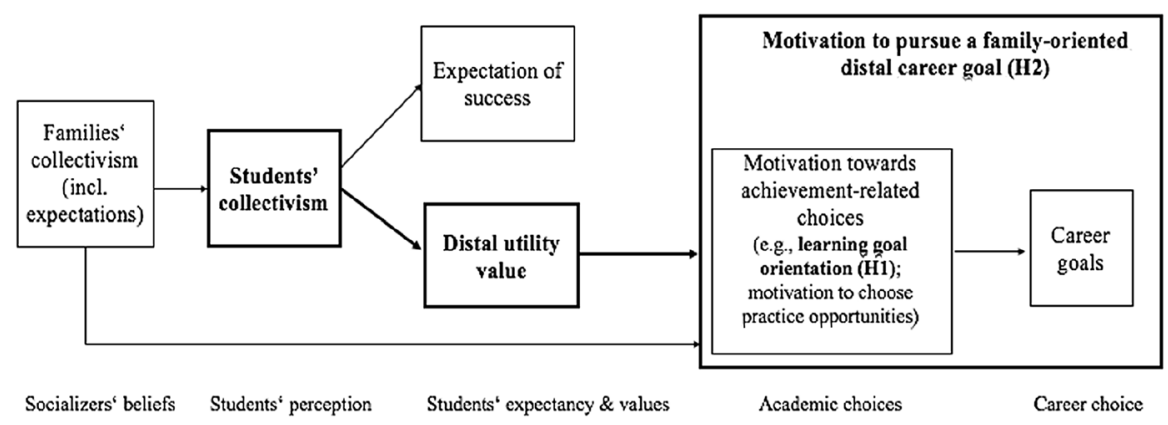

Figure 1 The expectancy-value model was modified and used as theoretical framework for the present study. Note. The arrows represent the theoretical relationships between variables. The bold arrows and variables highlight our main variables which we investigated in the present study. H1 refers to Hypothesis 1 and $\mathrm{H} 2$ refers to Hypothesis 2. 


\section{Collectivism}

\section{Core elements of collectivism}

In Western cultures, people tend to endorse cultural values that emphasize individual interests (Brewer \& Chen, 2007) and they view themselves as independent from others (Markus \& Kitayama, 1991). In contrast, in Eastern cultures people tend to endorse cultural values in which social embeddedness and being interdependent with others is pivotal (Brewer \& Chen, 2007; Markus \& Kitayama, 1991; Triandis, 1995). This distinction between Western and Eastern cultures is based on the cultural dimensions of individualism and collectivism (Brewer \& Chen, 2007). Individualism and collectivism both can vary between individuals within the context of culturally shared beliefs (Brewer \& Chen, 2007; Oyserman et al., 2002). One core element of collectivism is "the assumption that groups bind and mutually obligate individuals" (Oyserman et al., 2002, p. 5). This implies that collectivistic-oriented people follow more collective goals and group norms (Kemmelmeier, Burnstein, Krumov, Genkova, Kanagawa, Hirshberg, et al., 2003) and prioritize the interests of the ingroup (or family) over their individual interests for the sake of the ingroup (Singelis, Triandis, Bhawuk, \& Gelfand, 1995; Triandis, 1995). Research also suggests that doing the group a favor might result from the fulfillment of mutual obligations and expectations between group members (Markus \& Kitayama, 1991). Another central element of collectivism is a strong socioemotional relatedness to other members of the ingroup or family (Cross et al., 2000).

\section{The role of family expectations in collectivistic-oriented cultures}

In many collectivistic cultures, the family's actions are regarded as one's own actions; therefore, the family's success or honor reflects one's own success or honor and vice versa (Güngör, Karasawa, Boiger, Dinçer, \& Mesquita, 2014). This mechanism may lead families to have high expectations for members of the family to do well in the achievement context. For instance, previous studies revealed that fulfilling parents' achievement-related expectations was associated with respect, loyalty, and honor for the family for collectivistic students, leading these students to try to live up to their parents' expectations (Mosquera, Manstead \& Fischer, 2002; Phalet \& Claeys, 1993). These expectations might also hold during tertiary education (Bachelor's and Master's programs), as master's students with collectivistic orientation are motivated to study abroad to attend high-quality courses (mostly in Western countries), to desire to migrate after their graduation, and to improve their career prospects which are in line with their parents' career expectations (Wu, 2014).

\section{Achievement and career-related expectations and utility value}

Various studies have shown that collectivistic-oriented parents often emphasize the instrumentality or utility value of educational achievements (e.g., good grades, aspirations, learning) in order to increase their children's (and their own) life standards and economic situation in the future (Chen \& Wong, 2015; Kao \& Tienda, 
1995; Phalet \& Claeys, 1993). Having higher education, which in turn can increase one's economic situation in the future, is pivotal for collectivistic-oriented families because children are expected to financially support their parents (Mayer, Albert, Trommsdorf, \& Schwarz, 2005). The utility value of educational achievements is described by the expectancy-value model proposed by Eccles et al. (1983; Eccles \& Wigfield, 2002). Eccles and colleagues suggested in their model that the perceived value of a task or study subject and the expectancy for success are related to students' career choices (Eccles \& Wigfield, 2002). In their model, utility value is defined by "how well a task relates to current and future goals such as career goals" (Eccles \& Wigfield, 2002, p. 120) and can be more proximal (focus on immediate utility of the task) or distal (focus on long-term utility; Simons, Dewitte, et al., 2004). This means a person may ascribe a positive value to a learning task because it enhances future goals even if the person is not intrinsically interested in the task (Eccles \& Wigfield, 2002). Utility value interventions showed that Western students profited from an intervention which emphasized the proximal utility value, whereas East-Asian, collectivistic-oriented students profited from distal utility value interventions (Shechter et al., 2011). An ascribed positive utility value by collectivisticoriented students can be strongly shaped by their parents, as research has found that collectivistic-oriented parents have a strong influence on their children's career decisions even during adolescence (Garcia, Restubog, Toledano, Tolentino, \& Rafferty 2011; Sawitri, Creed, \& Zimmer-Gembeck, 2014). We assume that students with a high collectivistic orientation choose a career path that is consistent with the career wishes of their collectivistic-oriented parents. In other words, collectivistic students will do what the family thinks is best for them and act for the sake of their family (Singelis et al., 1995). Thus, we predict that for students with higher collectivistic orientation, the utility value of their study subject is likely in line with their parents' achievement and career-related expectations.

\section{Learning goal orientation for collectivistic-oriented students}

Utility value is closely associated with future goals (Simons, Vansteenkiste, et al., 2004). To attain future goals, different goal orientations can be considered. In the learning context, two goal orientations can be differentiated (Dweck \& Elliott, 1983; Dweck \& Leggett, 1988): A performance goal orientation focuses on the demonstration of one's abilities, whereas a learning goal orientation focuses on the adaption of goals with the aim of developing one's abilities. Individuals with a strong learning goal orientation believe that their skills and abilities are malleable so that they can improve their abilities by increasing effort on tasks (Dweck \& Leggett, 1988) and mastering new skills (Midgley, Kaplan, Middleton, Maehr, Urdan, Anderman, et al., 1998), whereas a performance goal orientation is associated with a stable and fixed view of one's ability.

Previous results on whether collectivistic-oriented individuals tend to hold stronger learning goal or performance goal orientations are mixed: Studies with collectivistic-oriented students (especially Chinese students) revealed that-due to the Confucian philosophy and its emphasis on personal development through education 
and competition in the achievement context-both learning goal orientation and performance goal orientation matter to them (Chen \& Wong, 2015; Salili \& Lai, 2003). However, findings on how collectivists deal with failure by focusing on selfimprovement (e.g., Heine, Kitayama, Lehman, Takata, Ide, Leung, 2001) highlight the relevance of learning goal orientations for collectivistic-oriented students. Moreover, some studies found that collectivistic-oriented students who believed that their intelligence and abilities were malleable pursued learning goals rather than performance goals (Chen \& Wong, 2015). Drawing on these findings, we predict that students' higher collectivistic orientation would be associated with higher learning goal orientation.

\section{The relationship between collectivism, distal utility value, and learning goal orientation}

Previous research has proposed categorizing goal orientation theory as one of the expectancy-value theories (e.g., Garcia \& Pintrich, 1994; Kaplan \& Maehr, 2007), as goal orientations are assumed to be related to values or goals (Kaplan \& Maehr, 2007). Supporting this, studies have found a positive association between learning goal orientations and individuals' perceptions of task value (e.g., Wolters, Shirley, \& Pintrich, 1996). A handful of studies have investigated the effects of utility value with regard to learning tasks or study majors for collectivistic students (e.g., Bong, 2001; Shechter et al., 2011). However, to our knowledge the interrelationships between collectivism orientation, utility value, and learning goal orientation for university students from different countries and cultural backgrounds have not yet been explored. As outlined above, collectivistic orientation may also implicitly include filial piety to fulfill the family's achievement-related expectations (e.g., Phalet \& Claeys, 1993), such that collectivistic-oriented students will treat expectations of their family as their own (Güngör et al., 2014). To meet such achievement-related expectations, it can be assumed that collectivistic-oriented students will be motivated to engage in a learning task or academic course work for the sake of their family's academic expectations in line with their collectivistic orientation (Phalet, Andriessen, \& Lens, 2004; Shechter et al., 2011). Thus, we assume that such a fulfillment of family-oriented achievement expectations as part of collectivism should be related to students' judgments of the utility value of their university coursework. Taken together, we hypothesize that the relationship between students' collectivistic orientation and learning goal orientation is mediated by the distal utility value of the university course work (Hypothesis 1, see also Figure 1).

\section{Future time perspective theory}

\section{Future time perspective and goals}

Endorsing collectivism and implicitly respecting the family's achievement expectations are not only important for the learning goal orientations of students, but also for goals in the more distant future. Distant future goals are essential within the 
framework of Future Time Perspective (FTP) theories, which highlight the importance of the motivation to pursue future goals (e.g., de Volder \& Lens, 1982; Nuttin \& Lens, 1985; Simons, Vansteenkiste, et al., 2004). FTP is defined as one's ability to anticipate future goals (Husman \& Lens, 1999; Nuttin \& Lens, 1985). By formulating motivational goals in the distant future, a longer FTP is created (de Volder and Lens, 1982; Husman and Lens, 1999), which enables people to remain motivated in activities in the present (e.g., working on immediate tasks) by anticipating events or consequences in the distant future (Husman \& Lens, 1999). There are various positive effects of FTP (e.g., on school grades; Zimbardo \& Boyd, 1999). However, to fully understand the effects of FTP, processes beyond these effects need to be explained. These processes are often embedded in learning contexts and can, for example, enhance deeper learning to attain future goals (Simons, Vansteenkiste, et al., 2004).

\section{Future goals and utility value}

We suggest that utility value is one crucial process variable. To preserve motivation for activities in the future, a high perceived utility value of present actions is necessary (Eccles \& Wigfield, 2002; Shechter et al., 2011). Studies have shown that collectivistic-oriented students appreciate instrumental distal goals like getting a good job more than individualistic-oriented students. For instance, Andriessen, Phalet, \& Lens (2006) found that collectivistic immigrant high school students judged the instrumentality of their major (i.e., for getting a good job) higher than native Dutch high school students. Drawing on these findings, it can be assumed that students with stronger collectivistic orientation are likely to have a longer FTP and, therefore, will judge the utility value of their present learning-related activities to be high even when the goals are in the very distant future (Shechter et al., 2011).

\section{Internalization of future goals and motivation}

Another factor that indirectly influences goal attainment is the process of goal internalization. Research has shown that future academic goals set by parents guide collectivistic-oriented students' motivation. For instance, Bao and Lam (2008) showed that fourth to sixth grade Chinese students' motivation to attend a course depended on their socioemotional attachment to a close person (i.e., mother). In detail, students with a strong emotional attachment to their mother showed high motivation even when the choice of an academic course was decided by their mother. This suggests that collectivistic-oriented individuals can be motivated when closely related persons make a choice for them in the academic context, because they might internalize the values and goals of close others due to their relatedness needs driven by their collectivistic orientation (Bao \& Lam, 2008; Chirkov, Ryan, Kim, \& Kaplan, 2003). This is in line with research showing that distal extrinsic academic goals (e.g., being motivated to do well in academic situations to get a good job; Kao \& Tienda, 1995) promote the motivation of collectivistic-oriented students to meet the expectations of their parents (for a metaanalysis on immigrant students, see Kim, Mok, \& Seidel, 2020; Mok, Martiny, Gleibs, Deaux, \& Froehlich, 2017; Phalet \& Claeys, 1993). For example, it was found that 
students of Turkish background living in Germany with strong endorsement of vertical collectivism (in comparison to those with weak endorsement) after activating a negative stereotype in an achievement situation showed a decrease in performance and were more motivated to collaborate with German students (who were stereotypically seen as more competent than Turkish migrants) in order to achieve a high-performance outcome in the future which is in line with their parents' achievement expectations (Mok et al., 2017).

Taken together, we predict a positive relationship between students' collectivistic orientation and the internalization of distal goals from their family, which can-in line with FTP findings (Husman \& Lens, 1999)_facilitate motivation for collectivistic-oriented students in present learning situations to pursue a future and family-oriented goal (e.g., attaining a respectable job position).

\section{Relationships between collectivism, distal utility value, and family-oriented distal career goals for university students}

Past research has provided various explanations as to why collectivistic- and individualistic-oriented students follow distal and proximal goals in a learning situation to a different degree (Bong, 2001; Shechter et al., 2011). In addition, the instrumentality of future goals has been shown to be more important to collectivistic-oriented than individualistic-oriented students (Bong, 2001; Shechter et al., 2011). For instance, an experimental study with (collectivistic-oriented) East-Asian and (individualistic-oriented) Western students revealed that a distal value manipulation for a learning task (i.e., framing a new math technique as useful for students' performance in future classes and careers) benefited East-Asian participants' motivational outcomes such as interest and effort more than a proximal value manipulation (i.e., framing the math technique as useful for students' daily life situations; Shechter et al., 2011). The opposite was the case for the Western students. These authors suggested that collectivistic-oriented students may also be strongly affected by distal utility value when choosing their majors. Thus, we propose that distal utility value might be linked to the attainment of future goals for collectivistic-oriented students.

Drawing on previous findings (Andriessen et al., 2006; Shechter et al., 2011), we predicted that collectivistic orientation would be positively associated with university students' judgments of the utility value of a university course of study, which in turn would affect students' motivation to attain FTP career goals (i.e., getting a good job) because their family's academic achievement- and career-related expectations matter to collectivistic-oriented children (e.g., Chen \& Wong, 2015; Verkuyten et al., 2001). Thus, we hypothesized that the relationship between students' collectivistic orientation and their motivation to follow family-oriented distal career goals would be mediated by the distal utility value of their university coursework (Hypothesis 2, see also Figure 1). 


\section{Method}

\section{Participants and procedure}

The present study had a correlational design. Data were collected via questionnaire at three different German universities. In accordance with regulations at German universities at the time of data collection in 2017, no ethics approval was needed for the study. Our study was in line with the ethical standards and general principals published by the APA in 2016. Before participants began the survey, the purpose of the study was explained and that the participation in the study was voluntary and anonymous. Participants were then asked to provide their informed consent. Initially 177 students participated in the study, but 23 students were excluded from the final sample because one of the following reasons: First, if participants already attended high school in Germany, they could not be classified as international university students. Second, we excluded participants who did not complete the questionnaire.

The final sample consisted of 154 international university students (100 females and 54 males) from over 40 different countries studying for a bachelor's or master's degree in Germany. The $44.2 \%$ of students were between 25 and 29 years, $35.1 \%$ of students were between 20 and 24 years old. Our aim was to attain a heterogenous sample of students from various countries because international university students are a particularly interesting target group for two reasons: first, collectivistic-oriented international students who choose to study abroad show a high learning motivation for their studies as they often strive to attain a good education and better career opportunities abroad (Chirkov, Vansteenkiste, Tao, \& Lynch, 2007). Second, sampling from heterogenous cultures consisting of varying levels of a relevant phenomenon (Boehnke, Lietz, Schreier, \& Wilhelm, 2011) allows us to collect data from a broader range of collectivistic-oriented university students to detect potential similarities on our indirect effects.

Recent research by Minkov, Dutt, Schachner, Morales, Sanchez, Jandosova, et al. (2017) has scored 56 countries on a collectivistic-oriented and individualistic-oriented index score identifying countries as more or less strongly collectivistic-oriented and individualistic-oriented. This collectivistic-oriented and individualistic-oriented index score was built on the well-known individualismcollectivism dimensions introduced by Hofstede (1980). More than $67 \%$ of all instruments measuring cultural values include measures from Hofstede's individualism-collectivism instrument (Taras, Rowney, \& Steel, 2009; Taras, Sarala, Muchinsky, Kemmelmeier, Singelis, Avsec, et al., 2014). According to Minkov et al.s' index score, strongly collectivistic-oriented countries include India, Thailand, and South Africa, moderately collectivistic-oriented countries include Colombia, Mexico, Brazil, and China, and less collectivistic-oriented countries include Poland, Turkey, and Romania (Minkov et al., 2017). Most of the students in our sample were from collectivistic-oriented regions such as Asia ( $n=67$ students; e.g., 6 from India, 4 from Singapore, and 12 from China), Africa ( $n=15$; e.g., 5 from South Africa), South America $(n=10$; e.g., 3 from Brazil). Other 
students were from Eastern Europe ( $n=23$; e.g., 6 from Romania), the rest of Europe $(n=21)$, and North America $(n=18)$. Students' ages ranged from 20 to 45 , with a standard deviation of 6 years.

\section{Measures}

\section{Collectivism}

To measure collectivism, we used seven items from the horizontal and vertical collectivism scale developed by Singelis et al. (1995; e.g., "Family members should stick together, no matter what sacrifices are required"; $\alpha=.74)$ to measure collectivism among participants from the diverse countries that either emphasize the horizontal (i.e., valuing equality and harmony among group or family members) or vertical dimension (i.e., valuing social hierarchies among group or family members and respect towards higher status members) of collectivism. Another reason why we combined both horizontal and vertical collectivism scales is that the four horizontal collectivism items reached only a rather low internal consistency of .65. Thus, we decided to use all items from both sub-scales to increase the internal consistency $(\alpha=.74)$. The answers of all items ranged from 1 "strongly disagree" to 6 "strong agree."

\section{Distal utility value}

The utility value of university coursework was assessed by adapted items from Eccles and Wigfield (1995; seven items ranging from 1 "strongly disagree" to 6 "strong agree," e.g., "Learning what I am expected to learn in my area of study is very useful for what I want to do after I graduate and go to work" or "It is important for me to get good grades from my program courses"; $\alpha=.81$ ). We selected these items because they reflect a more distal utility value.

\section{Learning goal orientation}

We used three items measuring learning goal orientation (e.g., "An important reason why I do my assignments is because I like to learn new things"; adapted from Midgley et al. (1998) for the university context; $\alpha=.79$ ). The answers ranged from 1 "strongly disagree" to 6 "strong agree."

\section{Motivation to pursue a family-oriented distal career goal (vignette)}

To assess participants' motivation to pursue a family-oriented distal career goal in a realistic and vivid setting, we created a vignette in which a typical learning situation and reasons for learning were described. As research postulated that motivation is domain- or situation-dependent (e.g., Magson, Bodkin-Andrews, Craven, Nelson, \& Yeung, et al., 2013; Wigfield, 1997) but previous FTP scales measure general goals (such as "Many opportunities await me in the future," Carstensen \& Lang, 1996), 
the aim of the vignette was to describe a concrete learning situation which is linked to specific future career goals. In this situation participants could express their motivation to practice in the present which is related to specific reasons in the present (i.e., family-driven achievement and career expectations) in order to attain a career goal in the future.

Motivation to pursue a family-oriented distal career goal in the vignette. Participants were asked to read a vignette about two university students and to imagine themselves in their place while reading. In the vignette, the motivations of the two fictional university students Sam and Pat were described. Both students were senior students in their study program and had received good grades in an important course. Both had the opportunity to study further by practicing an additional task (i.e., practicing the task for $28 \mathrm{~h}$ over 2 weeks of their leisure time), which might improve their final grade in the course. The two characters respond differently to this choice: Pat chooses not to work on the extra task, based on the argument that his or her grades are sufficient for a good job (i.e., an individual distal career goal). In contrast, Sam chooses to work on the extra task, based on the argument that having the best grades at university might be instrumental for a respectable and high-status career, which would satisfy the achievement expectations of Sam's family (i.e., a family-oriented distal career goal). After reading the vignette, participants assessed how likely they would be to choose Pat's path (as a proxy for their motivation related to an individual distal future goal) and Sam's path (as a proxy for their motivation related to a family-oriented distal future goal). The answers ranged from 1 "very unlikely" to 5 "very likely." For the present study, we report only the family-oriented distal career goal (Sam's path) as a dependent variable to test the second hypothesis.

Validity of the vignette assessing the motivation to pursue a family-oriented distal career goal. To test the validity of our vignette as measurement of the motivation to pursue a family-oriented distal career goal, we asked participants to explain their reasons for their given decision in the vignette (i.e., choosing Sam's path: working on an extra task in the present to potential attain a better job position in the future, see details of the vignette situation below). The majority of answers reflected the motivation in terms of FTP in a specific achievement situation (cf. Andriessen et al., 2006): Participants reflected on the benefits of engaging in an extra task in the current situation to potentially attain a better grade (e.g., "Because I view this [as] a golden chance given to even better my grades.") or higher job position in the future (e.g., "Career building is important to me, hard work pays off to future employers"). They also made explicit links of the reasons to their family (e.g., "I think doing extra tasks will make my family happy and proud of me. And I would like them to feel that way about me").

\section{Results}

The descriptive statistics for all four variables and their correlations are reported in Table 1. To test Hypothesis 1, we used the PROCESS macro developed by Hayes (2018, Model 4, 50,000 bootstrap samples). Results supported our hypothesis that utility value mediates the relationship between collectivistic orientation 
Table 1 Correlations and descriptive statistics

\begin{tabular}{|c|c|c|c|c|c|c|c|}
\hline & 1. & 2. & 3. & 4. & 5. & $M$ & $S D$ \\
\hline 1. Collectivistic orientation & - & & & & & 4.22 & 0.74 \\
\hline 2. Utility value & $.302 * *$ & - & & & & 4.53 & 0.71 \\
\hline 3. Learning goal orientation & .135 & $-.419 * *$ & - & & & 4.65 & 0.89 \\
\hline $\begin{array}{l}\text { 4. Motivation to pursue a } \\
\text { family-oriented distal career } \\
\text { goal }\end{array}$ & .055 & $.177 *$ & -.046 & - & & 3.38 & 1.18 \\
\hline
\end{tabular}

$* p<.05, * * p<.01$

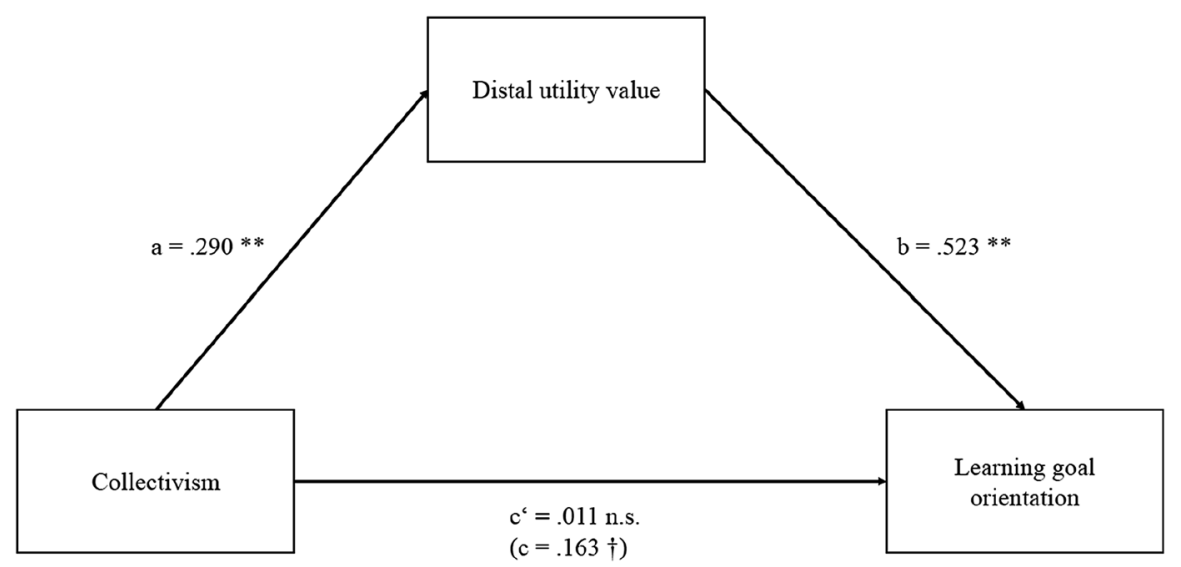

Figure 2 Mediation effect of distal utility value on the relationship between collectivism and learning goal orientation

Table 2 Mediation analysis of utility value on the relationship between collectivism and learning goal orientation

\begin{tabular}{|c|c|c|c|c|c|c|c|}
\hline & \multicolumn{3}{|c|}{ Mediator } & & \multicolumn{3}{|c|}{ Y (Learning goal orientation) } \\
\hline & Coeff & SE & $p$ & & Coeff & SE & $p$ \\
\hline \multirow{4}{*}{$\begin{array}{l}X \text { (collectivism) [a] } \\
M \text { (utility value) } \\
\text { Constant }[j \mathrm{l}\end{array}$} & \multirow[t]{2}{*}{0.29} & \multirow[t]{2}{*}{0.07} & \multirow[t]{2}{*}{$<.001$} & $c^{\prime}$ & 0.011 & 0.09 & .91 \\
\hline & & & & $\mathrm{b}$ & 0.523 & 0.10 & $<.001$ \\
\hline & $\begin{array}{l}3.30 \\
R^{2}=.0\end{array}$ & 0.32 & $<.001$ & iY & $\begin{array}{l}2.238 \\
R^{2}=.\end{array}$ & 0.50 & $<.001$ \\
\hline & $F(1,15$ & $4, p<$ & & & $F(2,1$ & $1, p<$ & \\
\hline
\end{tabular}

and learning goal orientation (see Figure 2 and Table 2). The bias-corrected bootstrap interval for the indirect effect was positive and did not include zero, which indicates a significant indirect effect $(a b=.15, \mathrm{CI}[.06 ; 29])$. The indirect effect revealed that collectivistic orientation predicted the utility value of their 


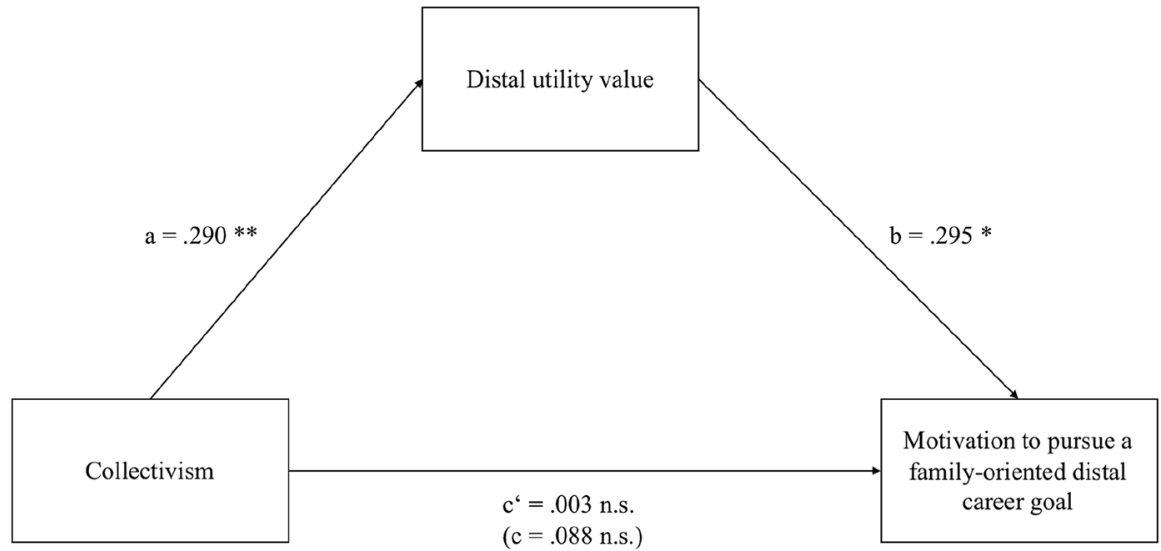

Figure 3 Mediation effect of distal utility value on the relationship between on motivation to pursue a family-oriented distal career goal

Table 3 Mediation analysis of utility value on the relationship between collectivism and the motivation to pursue a family-oriented distal career goal

\begin{tabular}{|c|c|c|c|c|c|c|c|}
\hline & \multicolumn{3}{|c|}{ Mediator } & & \multicolumn{3}{|c|}{$\begin{array}{l}\text { Y (motivation to pursue a } \\
\text { family-oriented distal career } \\
\text { goal) }\end{array}$} \\
\hline & Coeff & SE & $p$ & & Coeff & SE & $p$ \\
\hline \multirow{2}{*}{$\begin{array}{l}X \text { (collectivism) }[\mathrm{a}] \\
M \text { (utility value) }\end{array}$} & 0.29 & 0.07 & $<.001$ & $\mathrm{c}^{\prime}$ & 0.003 & 0.14 & .985 \\
\hline & & & & $\mathrm{b}$ & 0.295 & 0.14 & .037 \\
\hline \multirow[t]{3}{*}{ Constant [iM] } & 3.30 & 0.32 & $<.001$ & iY & 2.04 & 0.72 & .005 \\
\hline & \multicolumn{4}{|c|}{$R^{2}=.09$} & \multicolumn{3}{|c|}{$R^{2}=.03$} \\
\hline & \multicolumn{4}{|c|}{$F(1,152)=15.24, p<.001$} & \multicolumn{3}{|c|}{$F(2,151)=2.44, p=.091$} \\
\hline
\end{tabular}

university studies ( $a=.290)$, which in turn predicted learning goal orientation ( $b$ $=.523$ ). The total effect (i.e., the direct relationship between collectivistic orientation and learning goal orientation; $c=.163$; $\mathrm{CI}[-.03 ; .35]$ ) and the direct effect $\left(c^{\prime}=.011,[-.17 ; .20]\right)$ were not significant.

To examine Hypothesis 2, we again used the PROCESS macro by Hayes (2018; Model 4, 50,000 bootstrap samples). Results supported our hypothesis that utility value mediates the relationship between collectivistic orientation and the motivation to pursue a family-oriented distal career goal (see Figure 3 and Table 3). In detail, the bias-corrected bootstrap interval for the indirect effect was positive and did not include zero which indicates a significant indirect effect $(a b=.088$, CI $[.002 ; .20])$. As shown in Table 3 , collectivistic orientation predicted the utility value of their university studies $(a=.290)$, which in turn predicted participants' motivation to pursue a family-oriented distal career goal in the vignette ( $b$ 
$=.295)$. The total effect $(c=.088, C I[-.17 ; 35])$ and the direct effect $\left(c^{\prime}=.003\right.$;

$[-.26 ; .27])$ were not significant.

\section{Discussion}

The present study combines motivational theories (expectancy-value theory and FTP theories; Eccles et al., 1983; Nuttin \& Lens, 1985) and cross-cultural research (collectivism orientation; Singelis et al., 1995) into one expectancy-value-oriented theoretical framework by showing that collectivistic orientation, utility value, and both learning goal orientation and the motivation to pursue a family-oriented distal career goal are related. Results were in line with our two hypotheses. In detail, we found that collectivistic orientation predicted not only learning goal orientations but also the career goal motivation of international bachelor's and master's students from different countries indirectly via the distal utility value of their university coursework.

Our indirect effects have different theoretical contributions. First, concerning the mediation effects, showing that collectivistic orientation predicted students' individual distal utility value is in accordance with pivotal findings from cross-cultural research suggesting that individualism and collectivism as cultural orientations can co-exist on the individual level (Tamis-LeMonda, Way, Hughes, Yoshikawa, Kalman, \& Niwa, 2007; Verkuyten et al., 2001). Supporting this idea, it was found that collectivistic-oriented students' individual achievement motivation and their family-oriented achievement motivation were equally high (Verkuyten et al., 2001). In addition, Bao and Lam (2008) suggested that collectivistic children can maintain individual motivation in courses chosen by their mothers because they internalize the values and goals of closely related persons (e.g., family members). Our finding that collectivism predicts distal utility value, which in turn predicts familyoriented career goals in the future, seems to support this co-existence assumption for collectivistic-oriented university students in the academic and career decision context. Second, the result of the mediation analysis on learning goal orientation adds to the existing literature (Dweck \& Leggett, 1988) by revealing that university students from different countries endorsing collectivism engage in a learning goal orientation. This is also in line with research on the self-improvement motivation of collectivists who are likely to put more effort into learning activities after receiving failure feedback on an academic task (Heine et al., 2001). Third, to our knowledge, our study is the first to combine elements of expectancy-value theory (Eccles et al., 1983) and FTP theories (e.g., Nuttin \& Lens, 1985) to study collectivisticoriented university students from different countries. Moreover, we developed a new approach to assess university students' motivation by using a vignette describing an academic situation, in which students imagined themselves in the place of the characters and indicated their motivation to accomplish a family-related career goal in the distant future. The mediation effect on this motivational outcome was in accordance with our second hypothesis.

Our results are also of practical relevance. The mediation effect of distal utility value suggests that career counselors should take this type of motivation and the 
strong family relatedness of collectivistic-oriented university students into account. For example, career counselors can help students to stay motivated to achieve the university graduation and career goals by remembering the distal utility value of the studies and the family-related expectations in times where students are facing motivational challenges during learning or in examination periods. Such reflections of students' own distal utility value can positively affect international students' learning behavior (Eccles \& Wigfield, 2002) and achievement (Hulleman, Godes, Hendricks, \& Harackiewicz, 2010). Furthermore, the knowledge about the familyrelated career goals and FTP-oriented motivation in academic situations of collectivistic-oriented international university students might help university administrators and teachers to improve the curriculum for international students who often perceive more acculturative stress in the host country (Franco et al., 2019). In detail, university administrators and teachers can offer additional practice units in the university courses which will be graded in order to support the academic motivation of the international and more collectivistic-oriented students. Career counselors should also provide career advice in line with FTP-oriented motivation which enables students to show stronger effort in the present assignments or extra activities (such as internships) that increase the chances for a subsequent acceptance in an advanced study program or a higher job position. This support of international students by career counselors and university teachers is pivotal because successful international graduate students are needed in Germany and other European countries to address the skilled labor shortage for example in STEM professions (Winkelmann, 2001).

Finally, our findings are also in line with a study revealing benefits of a career counseling in Western countries that considers cultural values from students' cultural background. For instance, Arulmani (2011) showed in an intervention study with Indian students that a career counseling program that integrated cultural values of these students significantly reduced more negative career beliefs of students in comparison to the control group and to a career counseling program that did not integrated specific cultural values. Hence, career counselors should attend professional development on how cultural values of international students from different cultural backgrounds can be integrated in their counseling to address the needs of international students from non-Western cultures.

From a developmental perspective, some argue that collectivism, which includes relatedness to the family's wishes and expectations regarding academic outcomes, impacts only younger middle and high school students' learning goal orientation and career goal motivation (cf. Garcia et al., 2011). However, with regard to the core elements of collectivism such as the mutual obligations and strong relatedness to the family, our results suggest the influence of families' expectations and goals remain present for collectivistic-oriented university students (Fuligni, Tseng, V., \& Lam, 1999). Furthermore, the mediation effects on both outcomes are in accordance with research on the internalization of goals and achievement-related expectations of close others in collectivistic-oriented families (Bao \& Lam, 2008; Güngör et al., 2014). Thus, our results highlight the indirect role of these family-oriented goals and expectations for collectivistic-oriented adults (i.e., university students) in learning situations. 
Although we had a theoretical justification for expecting a relationship between students' collectivistic orientation and both their learning goal orientation and their motivation to pursue a family-oriented distal career goal, we did not detect a significant total effect. According to previous methodological suggestions (Hayes, 2018; Kenny \& Judd, 2013), the total effect and, therefore, the direct relationship between an independent variable and dependent variable, does not need to be significant in a mediation analysis. It is more important that the indirect effect indicating a mediation pattern is significant (Kenny \& Judd, 2013), which was the case in our study. The fact that the total effect was not significant, however, highlights the relevance of distal utility value in learning situations because utility value indirectly affects the relationship between collectivistic orientation of university students and their learning goal orientation and motivation to pursue a distal family-oriented career goal, even though the direct effect was not shown in our sample. Thus, universities should promote international students' distal utility value in the coursework. The finding of the indirect effect is also in line with social cognitive career theory (Lent, Brown, \& Hackett, 1994), suggesting that expectations of one's parents affect individual intentions to get involved in an activity, which in turn has an impact on activity selection and academic performance. Furthermore, consistent with the social cognitive career theory by Lent et al. (1994), additional practice opportunities can not only positively affect achievement of international students but also their self-efficacy beliefs which in turn affect outcome expectations, interest, goals, and activity selection. These practice opportunities with regard to social cognitive career theory outcomes might be especially important for the integration of international students with refugee status at higher education institutions in Germany. For instance, it was shown that Syrian students with refugee status in Germany often faced challenges due to lack of recognition of their previous qualifications or language barriers (Schneider, 2018). As a consequence, they have to restart a study program from which they have already graduated in their home country. Thus, we believe that additional practice opportunities which will be graded can also reduce frustration and help students to maintain their self-efficacy.

\section{Limitations}

The present study has some limitations. First, international university students from various countries were combined in the current sample, and due to the small numbers of students from each country, no analysis of single countries or subgroups of countries could be conducted. As our aim was to measure collectivism at the individual level, we did not focus on a specific ethnic group. This is in line with research suggesting that collectivism should be measured on the individual rather than the country level when predicting individual-level psychological variables (for a review, see Brewer \& Chen, 2007). In addition, investigating a heterogeneous sample allowed the collectivism orientation of university students to vary, in order to identify similarities across students from different countries in the hypothesized indirect effects on students' learning goal orientation and motivation to pursue a family-oriented distal career goal. Second, as we focused only on students' collectivism, we cannot 
draw conclusions about their individualism. Moreover, recent research has discussed whether individualism and collectivism are as unidimensional (high values of collectivism imply low values of individualism) or bidimensional (two independent dimensions; Taras et al., 2014). Hence, future studies should replicate our findings assessing individualism and collectivism separately. Third, our study was based on cross-sectional, correlational data. With this kind of data, we cannot investigate the actual learning behavior and career decisions of the students after their graduation from university. Hence, future research should investigate the longitudinal effects of our indirect effects on actual career decisions. Finally, previous research has identified different potential moderators of learning goal orientation and career interests (Darnon, Jury, \& Aelenei, 2018; Huang, Zhang, \& Hudson, 2018), which were not assessed in the present study. However, these moderators might also have an impact on our reported mediation effects. A potential moderator is the socio-economic status of university students. For instance, in a recent study (Darnon et al., 2018) it was revealed that social class moderated the effect of performance-approach goals on students' grades and marginally moderated the effect of mastery-approach goals on grades. They found a positive association between performance-approach goals and final grades only for students from a higher social class. On the other hand, masteryapproach goals were positively related to grades for lower social class students but not for higher social class students. It might be the case that socio-economic status also plays a role in determining the learning goal orientation and motivation to pursue a family-oriented distal career goal among university students who decided to study abroad. Thus, future research should take this moderator variable into account.

\section{Conclusion}

The present study shows that collectivistic orientation can predict international university students' learning goal orientations and motivation to pursue a distal career goal that is in line with the academic expectations and goals of their family indirectly, via the perceived distal utility value of their academic studies. The results combine motivational theories (expectancy-value theory and FTP theories; Eccles et al., 1983; Nuttin \& Lens, 1985) and cross-cultural research (collectivism orientation; Singelis et al., 1995). They also suggest that collectivistic-oriented international students living in Germany put great importance on their academic achievement, as they emphasize the utility value of their studies, which can in turn positively affect their learning goal orientation and their motivation to pursue career goals in the distant future. Thus, university administrators and teachers should consider the utility value and additional graded practice units which allow students to potentially improve their grades when planning or modifying university programs to support collectivistic-oriented students to attain their future academic and career goals. 
Authors' contributions SYM and CB contributed to the study conception and design. All three authors ( $\mathrm{SYM}, \mathrm{CB}$, and LF) contributed to the design of the vignette and the item selection in the questionnaire. Material preparation and data collection were performed by CB. Data analysis was performed by SYM. The first draft of the manuscript was written by SYM and all authors commented on previous versions of the manuscript. All authors read and approved the final manuscript.

Funding Open access funding provided by University of Zurich. The authors were not funded by any grants.

Data availability The data that support the findings of this study are available from the corresponding author (S.Y. Mok) upon reasonable request.

Code availability The code is available from the corresponding author (S.Y. Mok) upon reasonable request.

\section{Compliance with ethical standards}

Conflicts of interest The authors declare that they have no a conflict of interest.

Open Access This article is licensed under a Creative Commons Attribution 4.0 International License, which permits use, sharing, adaptation, distribution and reproduction in any medium or format, as long as you give appropriate credit to the original author(s) and the source, provide a link to the Creative Commons licence, and indicate if changes were made. The images or other third party material in this article are included in the article's Creative Commons licence, unless indicated otherwise in a credit line to the material. If material is not included in the article's Creative Commons licence and your intended use is not permitted by statutory regulation or exceeds the permitted use, you will need to obtain permission directly from the copyright holder. To view a copy of this licence, visit http://creativecommons.org/licen ses/by/4.0/.

\section{References}

Andriessen, I., Phalet, K., \& Lens, W. (2006). Future goal setting, task motivation and learning of minority and non-minority students in Dutch schools. British Journal of Educational Psychology, 76(4), 827-850. https://doi.org/10.1348/000709906X148150.

Arulmani, G. (2011). Striking the right note: the cultural preparedness approach to developing resonant career guidance programmes. International Journal for Educational and Vocational Guidance, 11(2), 79-93. https://doi.org/10.1007/s10775-011-9199-y.

Bao, X., \& Lam, S. (2008). Who makes the choice? Rethinking the role of autonomy and relatedness in Chinese children's motivation. Child Development, 79(2), 269-283. https://doi.org/10.1016/j.learn instruc.2010.03.002.

Bessey, D. (2012). International student migration to Germany. Empirical Economics, 42(1), 345-361. https://doi.org/10.1007/s00181-010-0417-0.

Blackwell, L. S., Trzesniewski, K. H., \& Dweck, C. S. (2007). Implicit theories of intelligence predict achievement across an adolescent transition: A longitudinal study and an intervention. Child Development, 78(1), 246-263. https://doi.org/10.1111/j.1467-8624.2007.00995.x.

Boehnke, K., Lietz, P., Schreier, M., \& Wilhelm, A. (2011). Sampling: The selection of cases for culturally comparative psychological research. In D. Matsumoto \& F. J. R. Van de Vijver (Eds.), Crosscultural research methods in psychology (pp. 101-129). Cambridge University Press.

Bong, M. (2001). Role of self-efficacy and task-value in predicting college students' course performance and future enrollment intentions. Contemporary Educational Psychology, 26(4), 553-570. https:// doi.org/10.1006/ceps.2000.1048. 
Brewer, M. B., \& Chen, Y.-R. (2007). Where (Who) are collectives in collectivism? Toward conceptual clarification of individualism and collectivism. Psychological Review, 114(1), 133-151. https://doi. org/10.1037/0033-295X.114.1.133.

Carstensen L. L., \& Lang F. R. (1996). Future time perspective scale. Stanford University.

Chen, W.-W., \& Wong, Y.-L. (2015). Chinese mindset: Theories of intelligence, goal orientation and academic achievement in Hong Kong students. Educational Psychology, 35(6), 714-725. https://doi. org/10.1080/01443410.2014.893559.

Cheung, C. S.-S., \& Pomerantz, E. M. (2012). Why does parents' involvement enhance children's achievement? The role of parent-oriented motivation. Journal of Educational Psychology, 5, 820832. https://doi.org/10.1037/a0027183.

Chirkov, V., Ryan, R. M., Kim, Y., \& Kaplan, U. (2003). Differentiating autonomy from individualism and independence: a self-determination theory perspective on internalization of cultural orientations and well-being. Journal of Personality and Social Psychology, 84(1), 97-110. https://doi. org/10.1037/0022-3514.84.1.97.

Chirkov, V., Vansteenkiste, M., Tao, R., \& Lynch, M. (2007). The role of self-determined motivation and goals for study abroad in the adaptation of international students. International Journal of Intercultural Relations, 31(2), 199-222. https://doi.org/10.1016/j.ijintrel.2006.03.002.

Cross, S., Bacon, P., \& Morris, M. (2000). The relational-interdependent self-construal and relationships. Journal of Personality \& Social Psychology, 78(4), 791-808. https://doi. org/10.1037/0022-3514.78.4.791.

Darnon, C., Jury, M., \& Aelenei, C. (2018). Who benefits from mastery-approach and performanceapproach goals in college? Students' social class as a moderator of the link between goals and grade. European Journal of Psychology of Education, 33(4), 713-726. https://doi.org/10.1007/s1021 2-017-0351-z.

Deci, E. L., \& Ryan, R. M. (2000). The 'What' and 'Why' of goal pursuits: Human needs and the selfdetermination of behavior. Psychological Inquiry, 11(4), 227. https://doi.org/10.1207/S15327965P LI1104_01.

Deci, E. L., \& Ryan, R. M. (2002). Handbook of self-determination research. University Rochester Press.

de Volder, M. L., \& Lens, W. (1982). Academic achievement and future time perspective as a cognitivemotivational concept. Journal of Personality and Social Psychology, 42(3), 566-571. https://doi. org/10.1037/0022-3514.42.3.566.

Dweck, C. S., \& Elliott, E. S. (1983). Achievement motivation. In P. H. Mussen \& E. M. Hetherington (Eds.), Handbook of Child Psychology (pp. 643-691). Wiley.

Dweck, C., \& Leggett, E. (1988). A social-cognitive approach to motivation and personality. Psychological Review, 95(2), 256-273. https://doi.org/10.1037/0033-295X.95.2.256.

Eccles, J., Adler, T. F., Futterman, R., Goff, S. B., \& Kaczala, C. M. (1983). Expectancies, values, and academic behaviors. In J. T. Spence (Ed.), Achievement and Achievement Motivation (pp. 75-146). Freeman.

Eccles, S. J., \& Wigfield, A. (1995). In the mind of the actor: The structure of adolescents' achievement task values and expectancy-related beliefs. Personality and Social Psychology Bulletin, 21(3), 215-225. https://doi.org/10.1177/0146167295213003.

Eccles, J. S., \& Wigfield, A. (2002). Motivational beliefs, values, and goals. Annual Review of Psychology, 53(1), 109-132. https://doi.org/10.1146/annurev.psych.53.100901.135153.

Franco, M., Hsiao, Y. S., Gnilka, P. B., \& Ashby, J. S. (2019). Acculturative stress, social support, and career outcome expectations among international students. International Journal for Educational and Vocational Guidance, 19(2), 275-291. https://doi.org/10.1007/s10775-018-9380-7.

Fuligni, A. J. (2001). Family obligation and the academic motivation of adolescents from Asian, Latin American, and European backgrounds. New Directions for Child and Adolescent Development, 2001(94), 61-76. https://doi.org/10.1002/cd.31.

Fuligni, A. J., Tseng, V., \& Lam, M. (1999). Attitudes toward family obligations among American Adolescents with Asian Latin American, and European backgrounds. Child Development, 70(4), 10301044. https://doi.org/10.1111/1467-8624.00075.

Garcia, T., \& Pintrich, P. R. (1994). Regulating motivation and cognition in the classroom: The role of self-schemas and self-regulatory strategies. In D. H. Schunk \& B. J. Zimmerman (Eds.), Self-regulation of learning and performance: Issues and educational applications (pp. 127-154). Lawrence Erlbaum Associates.

Garcia, P., Restubog, S. L. D., Toledano, L. S., Tolentino, L. R., \& Rafferty, A. E. (2011). Differential moderating effects of student- and parent-rated support in the relationship between Learning goal 
orientation and career decision-making self-efficacy. Journal of Career Assessment, 20(1), 22-33. https://doi.org/10.1177/1069072711417162.

Güngör, D., Karasawa, M., Boiger, M., Dinçer, D., \& Mesquita, B. (2014). Fitting in or sticking together: The prevalence and adaptivity of conformity, relatedness, and autonomy in Japan and Turkey. Journal of Cross-Cultural Psychology, 45(9), 1374-1389. https://doi.org/10.1177/0022022114542977.

Hayes, A. F. (2018). Introduction to mediation, moderation, and conditional process analysis: A regression-based approach (2nd Ed.). The Guilford Press.

Heine, S. J., Kitayama, S., Lehman, D. R., Takata, T., Ide, E., Leung, C., \& Matsumoto, H. (2001). Divergent consequences of success and failure in Japan and North America: An investigation of selfimproving motivations and malleable selves. Journal of Personality and Social Psychology, 81(4), 599-615. https://doi.org/10.1037/0022-3514.81.4.599.

Hoffmeyer-Zlotnik, P., \& Grote, J. (2019). Anwerbung und Bindung von internationalen Studierenden in Deutschland: Studie der deutschen nationalen Kontaktstelle für das Europäische Migrationsnetzwerk (EMN) [Recruiting and commitment of international students in Germany: a study from the German international reception center for the European migration network]. (Working Paper /Bundesamt für Migration und Flüchtlinge (BAMF) Forschungszentrum Migration, Integration und Asyl (FZ), 85). Nürnberg: Bundesamt für Migration und Flüchtlinge (BAMF) Forschungszentrum Migration, Integration und Asyl (FZ). Retrieved from https://nbn-resolving. org/urn:nbn:de:0168-ssoar-67593-8

Huang, X., Zhang, J., \& Hudson, L. (2018). Impact of math self-efficacy, math anxiety, and growth mindset on math and science career interest for middle school students: The gender moderating effect. European Journal of Psychology of Education. https://doi.org/10.1007/s1021 2-018-0403-z.

Hulleman, C. S., Godes, O., Hendricks, B. L., \& Harackiewicz, J. M. (2010). Enhancing interest and performance with a utility value intervention. Journal of Educational Psychology, 102(4), 880. https://doi.org/10.1037/a0019506.

Husman, J., \& Lens, W. (1999). The role of the future in student motivation. Educational Psychologist, 34(2), 113-125. https://doi.org/10.1207/s15326985ep3402_4.

Kao, G., \& Tienda, M. (1995). Optimism and achievement: The educational performance of immigrant youth. Social Science Quarterly, 76(1), 1-19.

Kemmelmeier, M., Burnstein, E., Krumov, K., Genkova, P., Kanagawa, C., Hirshberg, M. S., ... Noels, K. A. (2003). Individualism, collectivism, and authoritarianism in seven societies. Journal of Cross-Cultural Psychology, 34(3), 304-322. https://doi.org/10.1177/002202210303400 3005 .

Kenny, D. A., \& Judd, C. M. (2013). Power anomalies in testing mediation. Psychological Science, 25(2), 334-339. https://doi.org/10.1177/0956797613502676.

Kera, M., \& Nakaya, M. (2017). The effect of distal utility value intervention for students' learning. Bulletin of Teacher Education Center for the Future Generation, 3, 111-116.

Kim, Y., Mok, S. Y., \& Seidel, T. (2020). Parental influences on immigrant students' achievement-related motivation and achievement: A meta-analysis. Educational Research Review, 30, 100327. https:// doi.org/10.1016/j.edurev.2020.100327.

Lent, R. W., Brown, S. D., \& Hackett, G. (1994). Toward a unifying social cognitive theory of career and academic interest, choice, and performance. Journal of Vocational Behavior, 45(1), 79-122. https:// doi.org/10.1006/jvbe.1994.1027.

Magson, N. R., Bodkin-Andrews, G. H., Craven, R. G., Nelson, G. F., \& Yeung, A. S. (2013). Questioning new directions in understanding student motivation: An investigation into the domain specificity of motivational goals. The Educational and Developmental Psychologist, 30(2), 171-190. https:// doi.org/10.1017/edp.2013.11.

Markus, H. R., \& Kitayama, S. (1991). Culture and the self: Implications for cognition, emotion, and motivation. Psychological Review, 98(2), 224-253. https://doi.org/10.1037/0033-295X.98.2.224.

Mayer, B., Albert, I., Trommsdorf, G. and Schwarz, B. (2005) 'Value of children in Germany: Dimensions, comparison of generations, and relevance for parenting'. In G. Trommsdorff and B. Nauck (Eds.), The value of children in cross-cultural perspective: Case studies from eight societies (pp. 43-66). Pabst Science.

Meece, J. L., Anderman, E. M., \& Anderman, L. H. (2005). Classroom goal structure, student motivation, and academic achievement. Annual Review of Psychology, 57(1), 487-503. https://doi.org/10.1146/ annurev.psych.56.091103.070258. 
Midgley, C., Kaplan, A., Middleton, M., Maehr, M. L., Urdan, T., Anderman, L. H., ... Roeser, R. (1998). The development and validation of scales assessing students' achievement goal orientations. Contemporary Educational Psychology, 23, 113-131. https://doi.org/10.1006/ceps.1998.0965.

Minkov, M., Dutt, P., Schachner, M., Morales, O., Sanchez, C., Jandosova, J., ... Mudd, B. (2017). A revision of Hofstede's individualism-collectivism dimension: A new national intex from a 56-country study. Cross Cultural \& Strategic Management, 24(3), 386-404. https://doi.org/10.1108/ CCSM-11-2016-0197.

Mok, S. Y., Martiny, S. E., Gleibs, I. H., Deaux, K., \& Froehlich, L. (2017). The interaction of vertical collectivism and stereotype activation on the performance of Turkish-origin high school students. Learning and Individual Differences, 56, 76-84. https://doi.org/10.1016/j.lindif.2017.05.002.

Mosquera, P. M. R., Manstead, A. S. R., \& Fischer, A. H. (2002). Honor in the Mediterranean and Northern Europe. Journal of Cross-Cultural Psychology, 33(1), 16-36. https://doi.org/10.1177/00220 22102033001002.

Nisbett, R. E., Peng, K., Choi, I., \& Norenzayan, A. (2001). Culture and systems of thought: Holistic versus analytic cognition. Psychological Review, 108(2), 291-310. https://doi. org/10.1037/0033-295X.108.2.291.

Nuttin, J., \& Lens, W. (1985). Future time perspective and motivation, Leuven University Press and Erlbaum.

Oyserman, D., Coon, H. M., \& Kemmelmeier, M. (2002). Rethinking individualism and collectivism: Evaluation of theoretical assumptions and meta-analyses. Psychological Bulletin, 128(1), 3-72. https://doi.org/10.1037/0033-2909.128.1.3.

Phalet, K., \& Claeys, W. (1993). A comparative study of Turkish and Belgian youth. Journal of CrossCultural Psychology, 24(3), 319-343. https://doi.org/10.1177/0022022193243004.

Phalet, K., Andriessen, I., \& Lens, W. (2004). How future goals enhance motivation and learning in multicultural classrooms. Educational Psychology Review, 16(1), 59-89.

Pomerantz, E. M., \& Wang, Q. (2009). The role of parental control in children's development in Western and East Asian countries. Current Directions in Psychological Science, 18(5), 285-289. https://doi. org/10.1037/0033-295X.108.2.291.

Reynolds, A. L., \& Constantine, M. G. (2007). Cultural adjustment difficulties and career development of international college students. Journal of Career Assessment, 15(3), 338-350. https://doi. org/10.1177/10690.72707.30121.8.

Ryan, R. M., \& Deci, E. L. (2000). Intrinsic and extrinsic motivations: Classic definitions and new directions. Contemporary Educational Psychology, 25(1), 54-67. https://doi.org/10.1006/ ceps.1999.1020.

Salili, F., \& Lai, M. K. (2003). Learning and motivation of Chinese students in Hong Kong: A longitudinal study of contextual influences on students' achievement orientation and performance. Psychology in the Schools, 40(1), 51-70. https://doi.org/10.1002/pits.10069.

Sawitri, D. R., Creed, P. A., \& Zimmer-Gembeck, M. J. (2014). Parental influences and adolescent career behaviours in a collectivist cultural setting. International Journal for Educational and Vocational Guidance, 14(2), 161-180. https://doi.org/10.1007/s10775-013-9247-x.

Schneider, L. (2018). Access and aspirations: Syrian refugees' experiences of entering higher education in Germany. Research in Comparative and International Education, 13(3), 457-478. https://doi. org/10.1177/1745499918784764.

Shechter, O. G., Durik, A. M., Miyamoto, Y., \& Harackiewicz, J. M. (2011). The role of utility value in achievement behavior: The importance of culture. Personality and Social Psychology Bulletin, 37(3), 303-317. https://doi.org/10.1177/0146167210396380.

Simons, J., Dewitte, S., \& Lens, W. (2004a). The role of different types of instrumentality in motivation, study strategies, and performance: "Know why you learn, so you'll know what you learn!". British Journal of Educational Psychology, 74, 343-360. https://doi.org/10.1348/0007099041552314.

Simons, J., Vansteenkiste, M., Lens, W., \& Lacante, M. (2004b). Placing motivation and future time perspective theory in a temporal perspective. Educational Psychology Review, 16(2), 121-139. https:// doi.org/10.1023/B:EDPR.0000026609.94841.2f.

Singelis, T. M., Triandis, H. C., Bhawuk, D. P. S., \& Gelfand, M. J. (1995). Horizontal and vertical dimensions of individualism and collectivism: A theoretical and measurement refinement. CrossCultural Research, 29(3), 240-275. https://doi.org/10.1177/106939719502900302.

Song, J., \& Jiang, Y. (2019). The distinct roles of proximal and distal utility values in academic behaviors: Future time perspective as a moderator. Frontiers in Psychology. https://doi.org/10.3389/fpsyg .2019.01061. 
Tamis-LeMonda, C. S., Way, N., Hughes, D., Yoshikawa, H., Kalman, R., \& Niwa, E. (2007). Parents' goals for children: The dynamic coexistence of individualism and collectivism in cultures and individuals. Social Development, 17(1), 183-209. https://doi.org/10.1111/j.1467-9507.2007.00419.x.

Taras, V., Rowney, J., \& Steel, P. (2009). Half a century of measuring culture: Approaches, challenges, limitations, and suggestions based on the analysis of 112 instruments for quantifying culture. Journal of International Management, 15, 357-373.

Taras, V., Sarala, R., Muchinsky, P., Kemmelmeier, M., Singelis, T. M., Avsec, A., Coon, H. M., Dinnel, D. L., Gardner, W., Grace, S., Hardin, E. E., Hsu, S., Johnson, J., Aygün, Z. K., Kashima, E. S., Kolstad, A., Milfont, T. L., Oetzel, J., Okazaki, S., ..., Sinclair, H. C. (2014). Opposite ends of the same stick? Multi-method test of the dimensionality of individualism and collectivism. Journal of CrossCultural Psychology, 45(2), 213-245. https://doi.org/10.1177/0022022113509132

Triandis, H. C. (1995). Individualism and collectivism. Westview.

Vansteenkiste, M., Lens, W., \& Deci, E. (2006). Intrinsic versus extrinsic goal contents in self-determination theory: Another look at the quality of academic motivation. Educational Psychologist, 41(1), 19-31. https://doi.org/10.1207/s15326985ep4101_4.

Vansteenkiste, M., Simons, J., Lens, W., Soenens, B., Matos, L., \& Lacante, M. (2004). Less is sometimes more: Goal content matters. Journal of Educational Psychology, 96(4), 755-764. https://doi. org/10.1037/0022-0663.96.4.755.

Verkuyten, M., Thijs, J., \& Canatan, K. (2001). Achievement motivation and academic performance among Turkish early and young adolescents in the Netherlands. Genetic, Social, and General Psychology Monographs, 127(4), 378-408.

Wigfield, A. (1997). Reading motivation: A domain-specific approach to motivation. Educational Psychologist, 32(2), 59-68. https://doi.org/10.1207/s15326985ep3202_1.

Wigfield, A., \& Eccles, J. S. (2000). Expectancy-value theory of achievement motivation. Contemporary Educational Psychology, 25(1), 68-81. https://doi.org/10.1006/ceps.1999.1015.

Wigfield, A., Tonks, S. \& Eccles, J. (2004). Expectancy-value theory in cross-cultural perspective. In McInerny, D. M. and Van Etten, S. (Eds.). Big theories revisited. Volume 4 in research on sociocultural influences on motivation and learning (pp. 165-198). Information Age Publishing.

Winkelmann, R. (2001). Why do firms recruit internationally? IZA Discussion Papers, No. 331. Institute for the Study of Labor (IZA).

Wolters, C. A., Shirley, L. Y., \& Pintrich, P. R. (1996). The relation between goal orientation and students' motivational beliefs and self-regulated learning. Learning and Individual Differences, 8(3), 211-238. https://doi.org/10.1016/S1041-6080(96)90015-1.

Wu, Q. (2014). Motivations and decision-making processes of mainland Chinese students for undertaking master's programs abroad. Journal of Studies in International Education, 18(5), 426-444. https:// doi.org/10.1177/1028315313519823.

Zimbardo, P. G., \& Boyd, J. N. (1999). Putting time in perspective: A valid, reliable individual-differences metric. Journal of Personality and Social Psychology, 77(6), 1271-1288. https://doi. org/10.1037/0022-3514.77.6.1271.

Publisher's Note Springer Nature remains neutral with regard to jurisdictional claims in published maps and institutional affiliations. 